\title{
Pathogenicity of Selected Kenyan Entomopathogenic Nematodes of Genus Steinernema against Banana Weevil (Cosmopolites Sordidus)
}

\author{
Moses Mwaniki Ndiritu' ${ }^{1}$ \\ Dora Kilalo 2 \\ John Wangai Kimenju ${ }^{3}$ \\ Shelmith Waruguru Mwaniki ${ }^{4}$
}

\author{
1,2,3 Department of Plant Science and Crop Protection \\ Faculty of Agriculture; University of Nairobi \\ ${ }^{4}$ Kenya Agricultural and Livestock Research \\ Organization (KALRO-Kabete) \\ ( Corresponding Author)
}

\begin{abstract}
Banana weevil is a pest with a great impact on banana production in the world. The objective of this study was to evaluate the pathogenicity of the Kenyan entomopathogenic nematodes (EPNs) of genus Steinernema against the weevil Cosmopolites sordidus (Germar) under laboratory conditions. Adult weevils were trapped from banana fields in Maragua, Central Kenya and larvae extracted from the infested banana rhizomes. The adults were treated with three Kenyan EPNs Steinernema weiseri, Steinernema yirgalemense and the new Steinernema spp and with Steinernema carpocapsae ALL strain as a standard and plain distilled water as a control in five replicates. The treatments were 500ijs, 750ijs and 1000ijs per adult on petri dishes and 1000ijs, 3000ijs and 5000ijs per adult on pseudo-stems. The treatments for larvae in petri dishes were $300 \mathrm{ijs}, 400 \mathrm{ijs}$ and $500 \mathrm{ijs}$. The adults were not susceptible to all the nematodes at all doses and preparations while larvae were highly susceptible to the four test EPNs at all concentrations. There was a significant difference at $\mathrm{P}<0.05$ in the mortality of larvae between nematode Steinernema carpocapsae and Steinernema weiseri. A significant difference was observed between nematode Steinernema carpocapsae and Steinernema yirgalemense. There was also a significant difference between the new Steinernema spp and Steinernema weiseri and finally in the two nematodes the new Steinernema spp and Steinernema yirgalemense. All the test nematodes caused over $90 \%$ larval mortality within 48 hours. The mean percent mortality of larva increased with nematode concentration for all the test nematodes. The results indicated that the four test EPNs significantly $(\mathrm{P}<0.05)$ caused high mortality within $24-48 \mathrm{hrs}$. The findings indicate that the banana weevil larvae are susceptible to the local entomopathogenic nematodes and potentially useful in the management of the banana weevil. It is however recommended that more research be conducted on the formulation and application technology to enhance their effectiveness in the field.
\end{abstract}

Keywords: Banana, Cosmopolites sordidus, Management, Entomopathogenic nematodes, Steinernema spp.

\section{Contents}

1. Introduction.

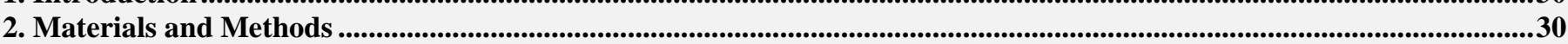

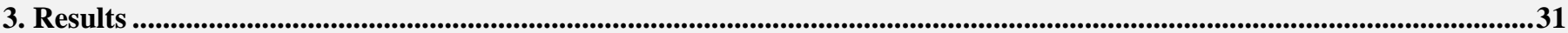

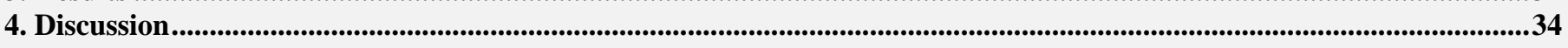

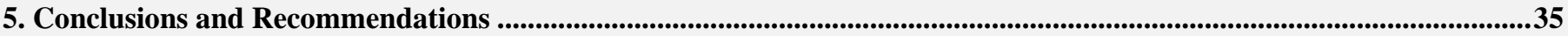

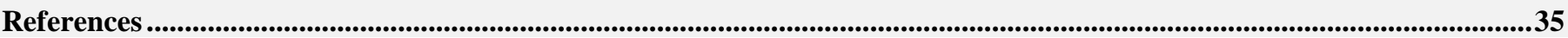

Citation | Moses Mwaniki Ndiritu; Dora Kilalo; John Wangai Kimenju; Shelmith Waruguru Mwaniki (2016). Pathogenicity of Selected Kenyan Entomopathogenic Nematodes of Genus Steinernema against Banana Weevil (Cosmopolites Sordidus). Agriculture and Food Sciences Research, 3(1): 2936.

DOI:

ISSN(E) :

$\operatorname{ISSN}(\mathbf{P}):$

$\begin{array}{ll}\text { Licensed: } & \text { This work is licensed under a Creative Commons Attribution 3.0 License }(\mathrm{cc}) \mathrm{EY} \\ \text { Contribution/Acknowledgement: } & \text { All authors contributed to the conception and design of the study. We are grateful to the University of Nairobi for }\end{array}$

10.20448/journal.512/2016.3.1/512.1.29.36 crossre 2411-6653

$2411-6653$ All authors contributed to the conception and design of the study. We are grateful to the University of Nairobi for
offering us the opportunity to pursue the study and to the National Council for Science and Technology for supporting the research work. We appreciate the assistance of the agriculture extension officer and farmers of Maragua region of

Funding:
Competing Interests: Murang'a County for their support.
This study received no specific financial support.

Transparency:

The authors declare that they have no conflict of interests.

The authors confirm that the manuscript is an honest, accurate, and transparent account of the study was reported; that no vital features of the study have been omitted; and that any discrepancies from the study as planned have been explained.

History:

Ethical:

Received: 11 May 2016/ Revised: 30 May 2016/ Accepted: 6 June 2016/ Published: 10 June 2016

Publisher:

This study follows all ethical practices during writing.

Asian Online Journal Publishing Group 


\section{Introduction}

Entomopathogenic nematodes (EPNs) of the families Steinernematidae and Heterorhabditidae have been exploited for several decades as biological tools against many important insect pests in the world [1]; [2]. This has been made possible due to major advances in understanding the natural behavior of these nematodes [3]. They have also been studied intensively because of their ability to cause natural mortality of soil dwelling arthropods hence potential as biocontrol agents [4]. Use of EPN was part of integrated population suppression of pine weevil in the United Kingdom [5]. They have been reported to control sweet potato weevils in India and Kenya [6]. In addition, use of S.carpocapsae as a biological control against flat-headed root dwelling weevils in roots of apricot trees achieved $95 \%$ control [7].

Many researchers in the world are working on these important biological controls [8]. Of these, research on status of commercially available EPNs have been carried out intensively in North American countries and Europe while in Asian countries including China, Korea and India the much stressed research work is on the use of EPNs to control insect pests and plant pathogens [8]. For most African countries EPN research is still being carried out and in some countries non-existent. In developing countries more emphasis and interest is in the mutualistic relationship between the EPNs and bacteria hence the need to use them as biological agents for soil pests [8]. The EPNs are also commercially available in many parts of the world [9]. Studies on the occurrence of EPNs in Africa have been reported. The first record of both families was in a survey done in Nigeria where H. bacteriophora and S. feltiae were reported [10]. A number of surveys have been documented showing new species and strains isolated from African countries. These have been found to have widespread abundance and are associated with types of habitats in South Africa, Kenya, Ethiopia and Egypt [11]; [12]; [13]; [14]; [15]; [16]; [17].

The EPNs were first reported in Kenya in a survey conducted in the Central highlands and Coastal areas of Kenya where a total of 154 nematode isolates among them the new species Steinernema karii was identified [18]; [19]. Further surveys in the Rift valley yielded 12 nematode isolates (Mwaniki, pers com.). Currently 33 nematode isolates are maintained in three laboratories at Kenya Agricultural and Livestock Research Organization (Mwea, Thika and Kabete). The most studied genera are those that are useful in the control of insect pests, the Steirnematidae and Heterorhabitidae [20]. They have been identified in Kenya with different species described in Central Highlands, Rift Valley and Coastal areas [21]. The banana weevil is the major banana pest in wherever bananas are grown. It originated from South East Asia [22] and it is now found in all banana growing regions including the New World, Afro tropics, and Oriental and Australasian regions [23]. It came into the African continent from the South East Asia through infested planting material and has since established in banana production areas within the continent such as Nigeria, Rwanda, Democratic Republic of Congo, Uganda, Tanzania and Kenya [22]. It is a major pest in East Africa [24]. Banana weevil is a Coleopteran insect [23]. The adult weevil is nocturnal and very susceptible to desiccation and it rarely flies [22]. The newly emerged adult is red brown but turns black two to three days later [23]. It measures about $12 \mathrm{~mm}$, hard shelled and it has a pronounced snout. The larva is the most destructive stage [22]. They develop from the eggs and get into the corms and sometimes in the pseudo-stems making numerous tunnels. The tunneling interferes with root initiation and development, nutrient and water uptake there by weakening the plant leading to production of a bunch with less weight or eventual death [24]. This study was undertaken to evaluate the pathogenicity potential of the Kenyan entomopathogenic nematodes (EPNs) of genus Steinernema against the weevil (Cosmopolites sordidus) (Germar) under the laboratory conditions.

\section{Materials and Methods}

\subsection{Entomopathogenic Nematodes}

Laboratory investigations were carried out in the entomology laboratory of Kenya Agricultural and Livestock Research Organization (KALRO) Kabete in Nairobi. Entomopathogenic nematodes were obtained from the entomology laboratory. Multiplication of the nematodes was done by the in-vivo method where the insect-bait technique with Galleria mellonella larvae described by Poinar [25] and modified by Woodring and Kaya [26]; Parra [27]. Four nematode species were tested against the adult weevil and the larval stage of the banana weevil. These were the new Steinernema sub spp, Steinernema carpocapsae ALL strain, Steinernema weiseri and Steinernema yirgalemense. Three selected EPNs Steinernema sub spp, Steinernema weiseri and Steinernema yirgalemense had been isolated from Kenyan soils. Steinernema carpocapsae ALL strain was used for comparison purposes as it is a widely tested species. Infective juveniles were kept in aqueous suspension in plastic containers with perforated lids at room temperatures and used in the experiment seven days after harvesting.

\subsection{Banana Weevils}

Adult of $C$. sordidus were trapped using pseudo-stem traps placed in banana orchards in Maragua $\left(0^{\circ} 46^{\prime} 59^{\prime \prime} \mathrm{S}\right.$ and $37^{\circ} 07^{\prime} 59^{\prime \prime}$ E) in Central Kenya. They were transferred to the laboratory, and maintained in perforated plastic buckets with moistened soil and pieces of banana pseudo-stems and corms. They were covered with opaque clothing and kept at room temperature. They remained until their use in experiment. Every week, there was exchange of soil and both pseudo-stem pieces and corms. In addition, banana corms heavily infested with weevil larvae were obtained from banana orchards from Maragua and transferred in plastic bags to the laboratory. Weevil larvae were extracted the following day by opening up the corms that were characterized by holes due to infestation. They were carefully handled to avoid any injury or mortality before the assay was carried out. The extracted larvae were removed and immediately inoculated with nematode treatments.

\subsection{Pathogenicity Tests}

Procedures for inoculation and incubation were the same as those used for entomopathogenic nematode multiplication with Galleria mellonella larvae [25] modified by Woodring and Kaya [26]; Parra [27]. The only 
difference was that this time adult and larval stages of the banana weevil were used instead of the normal last instar stage of wax moth.

The design for all the bioassay experiments was completely randomized with five treatments, each treatment had five replicates and the experimental unit consisted of six petri dishes $9 \mathrm{~cm}$ in diameter with 3 banana weevil adults or larvae.

In the first bioassay experiment adult weevils were used as the target insect pests to test the laboratory pathogenicity of the selected entomopathogenic nematodes. Four entomopathogenic nematodes were used as described above. Five adult weevils were introduced in sterilized petri dishes per nematode species. Filter papers were lined on the surface of petri dish to drain the excess water that carried the nematode suspension. Inoculation was done by introducing aqueous suspension containing nematodes through sterilized pipette that was specific for each nematode treatment. Each nematode treatment was replicated five times. Three different nematode concentrations were used and they included: $500 \mathrm{Ijs}$, $750 \mathrm{Ijs}$ and $1000 \mathrm{Ijs}$ per adult weevil in the petri dish and a control that contained plain distilled water only. This first experiment was repeated using the same procedure. After the inoculation, each petri dish was sealed with parafilm. The contents were then transferred to a dark chamber at room temperature. Observations for mortality were made at 24 hours, 48 hours, 72 hours and 96 hours. The weevils were dissected under a light microscope to confirm nematode infection.

A second bioassay with adult weevils was conducted using the same procedure but this time with a much higher dose of entomopathogenic nematodes. The dosage levels were $1000 \mathrm{Ijs}, 3000 \mathrm{Ijs}$ and $5000 \mathrm{Ijs}$ per adult weevil and plain distilled water was used as a control. Observations were done as before. This bioassay was also done twice.

A third bioassay with the adult weevil was conducted by using pseudo-stems which were laced with EPNs. Small blocks of pseudo-stem of the same size were cut from a fresh banana pseudo-stem. Each nematode treatment was applied to the small blocks using a hand pump. This was done all around to maximize the introduction of nematodes. Sterilized plastic containers were used in place of petri dishes. They were lined up with filter papers at the bottom so as to drain excess water. The same nematode concentration was applied as in the second weevil bioassay. Only one weevil was introduced per treatment with five replications. Plain distilled water was used as the control per concentration level.

The last bioassay involved the use of banana weevil larvae. The procedure was similar to the first bioassay that was conducted using the adult weevil. However, the number of larvae introduced per petri dish was three and the concentrations were 300, 400 and 500ijs per larval stage. Nematode suspensions were introduced into the petri dishes through a sterilized pipette. Plain distilled water was used as a control. Each concentration level was replicated five times. The petri dishes were then closed and sealed with parafilm. They were then incubated at room temperature in dark chambers. The experiment was done twice.

Observations for mortality were made every 24 hours up to 96 hours. A dead treatment was still with no response after brushing. Cadavers infected with the nematodes were pale in color. Cadavers were dissected under a light microscope to confirm presence of EPNs. The number of the dead larvae was recorded.

\subsection{Statistical Analysis}

The mortality data was subjected to one and two way analysis of variance (ANOVA). Mean separation of the treatments that were significantly different at $\mathrm{P} \leq 0.05$ was done using the Turkey-cramers comparison test. The analysis was done to compare the pathogenicity of the selected local entomopathogenic nematodes and test their effectiveness against banana weevil adult and larval stage.

\section{Results}

\subsection{Pathogenicity of Different Entomopathogenic Nematodes on the Adult Stage of the Banana Weevil under Laboratory Conditions}

Adult weevils were not susceptible to all the four entomopathogenic nematodes at all concentrations in all the test arenas and time periods in the three bioassay experiments.

\subsection{Comparison of Pathogenicity and Virulence of Selected Entomopathogenic Nematodes against the Larvae of Banana Weevil under Laboratory Conditions}

All the test nematodes were pathogenic to the larvae of Cosmopolites sordidus. The dead larvae got a soft consistency and a yellow-brown to black colour (pale), a characteristic of larvae killed by the bacteria of the genus Xenorhabdus associated with Steinernema species [28]. The mean mortality for each test EPN differed though not significant in both the experiments which were carried out under the same conditions. The mean mortality for $S$. yirgalemense spp ranged from (2.00-2.20), new Steinernema spp (2.40-2.55), S.weiseri spp (2.20-2.33) and Steinernema carpocapsae spp (2.60-2.73). There was no mortality recorded in the control treatment in both experiments (Figures 1 and 2). 


\section{Bioassay 1}

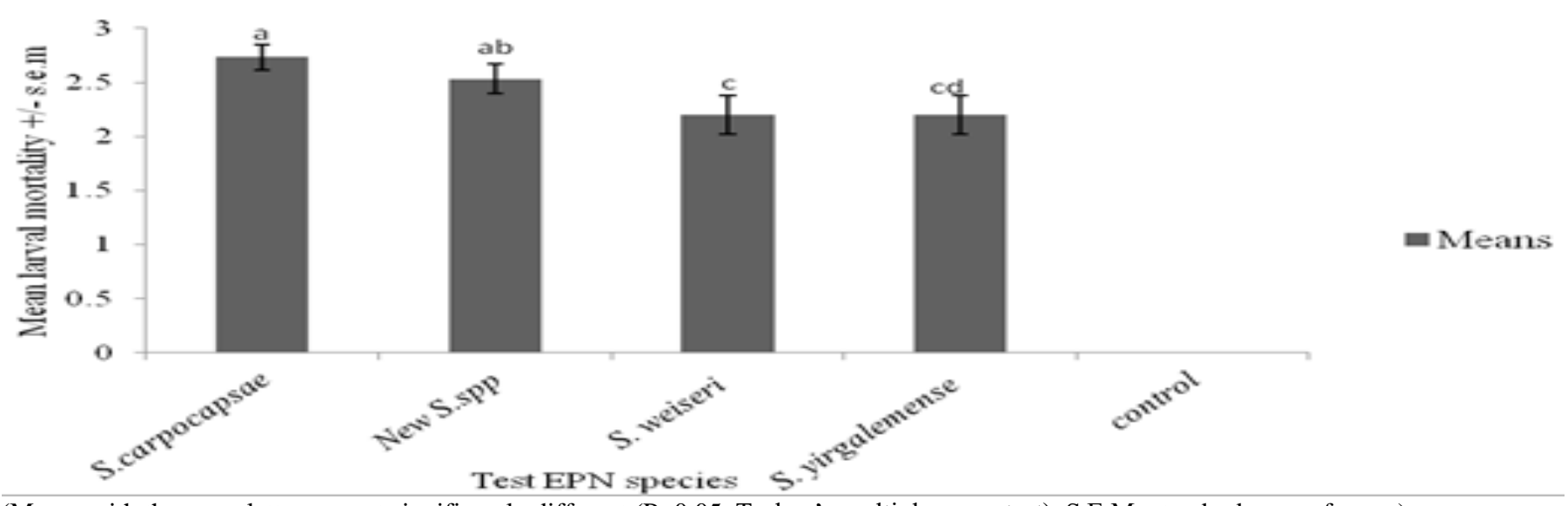

(Means with the same letter are not significantly different ( $\mathrm{P} \leq 0.05$, Turkey's multiple range test). S.E.M -standard error of mean)

Figure-1. Mean mortality of banana weevil larvae following $96 \mathrm{hr}$ of exposure to infective juveniles of selected EPNs in the one-on-one assay. Source: KALRO- Kabete

There was a significant difference $(\mathrm{P} \leq 0.05)$ in mortality of weevil larvae attributed to the three nematode species. The mean mortality of banana weevil larvae caused by S.carpocapsae spp was significantly higher $(\mathrm{P} \leq 0.05)$ compared to S.weiseri spp and S.yirgalemense spp (Figure 1).

More so, a significant difference at $(\mathrm{P} \leq 0.05)$ was observed between nematode new Steinernema spp and S.weiseri spp; new Steinernema spp and S.yirgalemense spp (Figure 1). However, no significant difference (P $\geq 0.05)$ was observed between nematode S.carpocapsae spp and new Steinernema spp (Figures 1 \& 2) S.weiseri spp and S.yirgalemense spp (Figures 1) S.carpocapsae spp and S.weiseri spp; new Steinernema spp and S.weiseri spp (Figure 2).

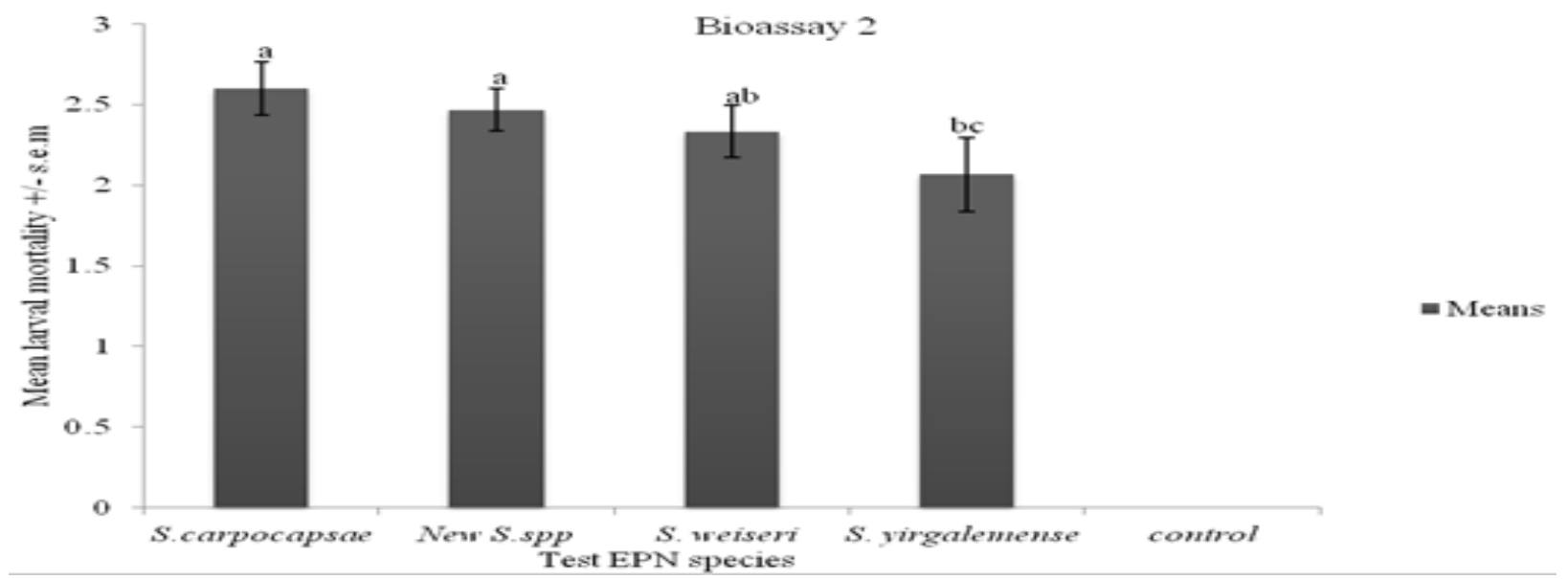

(Means with the same letter are not significantly different ( $\mathrm{P} \leq 0.05$, Turkey's multiple range test). S.E.M -standard error of mean) Figure-2. Mean mortality of banana weevil larvae following $96 \mathrm{hr}$ of exposure to infective juveniles of selected EPNs the one-on-one assay. Source: KALRO- Kabete

S.carpocapsae spp was found to be the most pathogenic and virulent among the tested EPNs in both larval assays compared to other test nematodes as shown in Figures 1 and 2 above.

\subsection{Comparison of Banana Weevil Larvae Mortality Recorded At Different Time Periods in an Assay under Laboratory Conditions}

There were significant differences $(\mathrm{P} \leq 0.05)$ between the exposure times of larvae to the test entomopathogenic nematodes as shown in Figures 3 and 4 below.
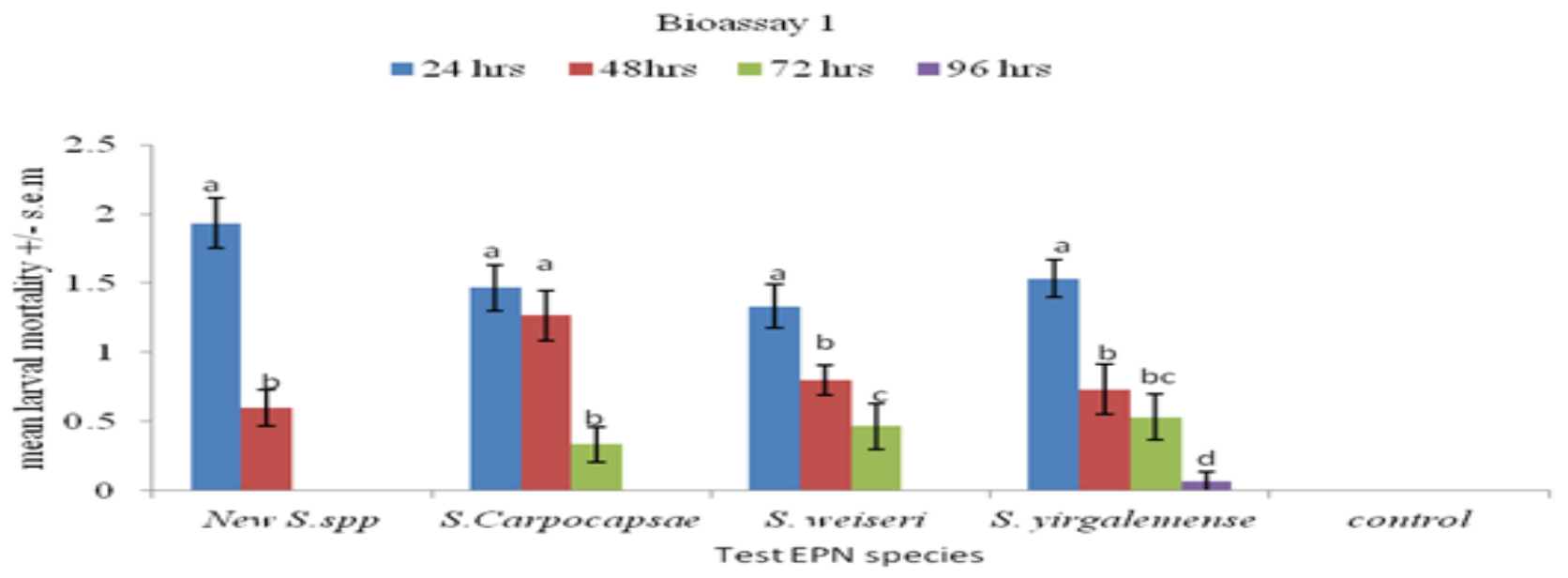

(Means with the same letter are not significantly different ( $\mathrm{P} \leq 0.05$, Turkey's multiple range test). S.E.M -standard error of mean)

Figure-3. Mean mortality of banana weevil larvae recorded after exposure to infective juveniles of selected EPNs for a variable time periods. Source: KALRO- Kabete 


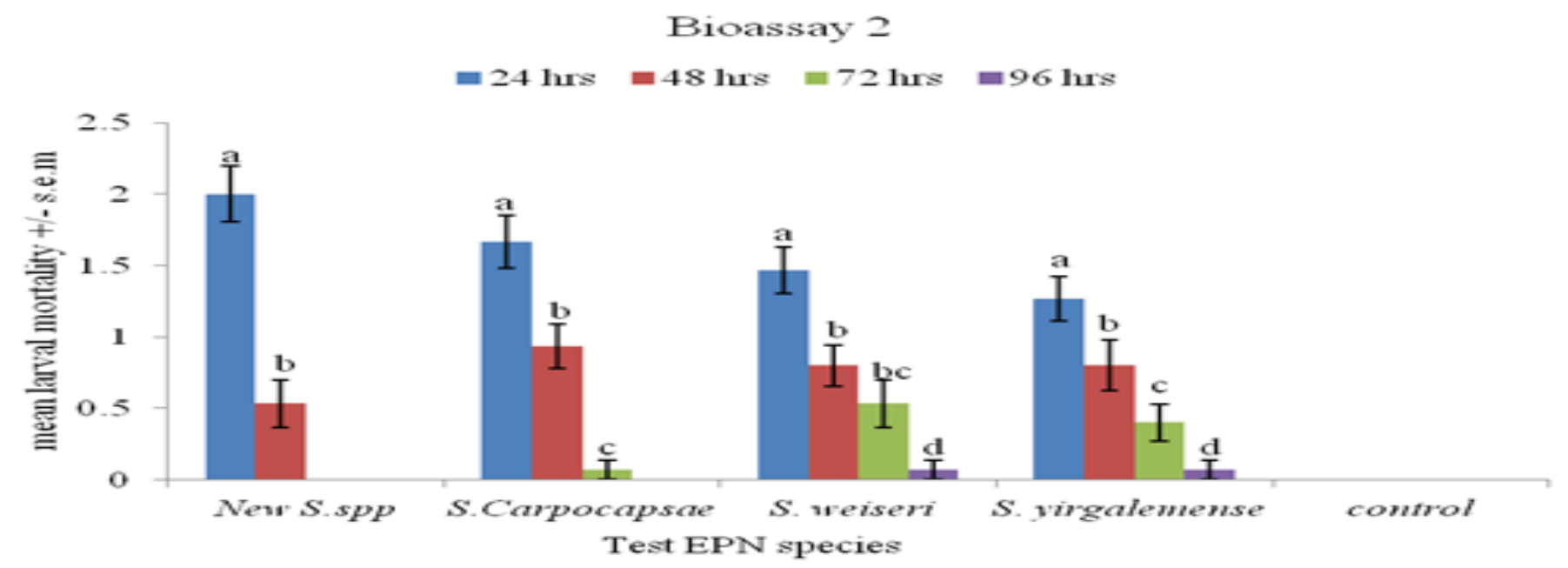

(Means with the same letter are not significantly different $(\mathrm{P} \leq 0.05$, Turkey's multiple range test). S.E.M -standard error of mean)

Figure-4. Mean mortality of banana weevil larvae recorded after exposure to infective juveniles of selected EPNs for a variable time periods.

Source: KALRO- Kabete

All the nematodes tested caused a high mortality of banana weevil larvae within the first 24 hrs of exposure (Figures 3 and 4) but except for S.carpocapsae (Figure 3). The new Steinernema spp caused significantly $(\mathrm{P} \leq 0.05)$ higher mortality within $24 \mathrm{hrs}$ than the rest of the test nematodes.

It took only 48 hrs for the new Steinernema spp to cause more than $90 \%$ larval mortality. S.weiseri spp and S.yirgalemense spp took the longest time period to cause more than $90 \%$ larval mortality. However, at 48 hrs exposure time S.carpocapsae spp achieved a significantly higher $(\mathrm{P} \leq 0.05)$ mean mortality compared to other test nematodes (Figures 3 and 4).

\subsection{Effect of Ijs Concentrations on the Mortality of Banana Weevil Larvae in a Dose-Response Study under Laboratory Conditions}

In this study, the results indicated that the mean mortality of banana weevil larvae increased with increasing nematode concentration (300ijs, 400ijs and 500ijs) as shown in Figures 5 and 6 below.

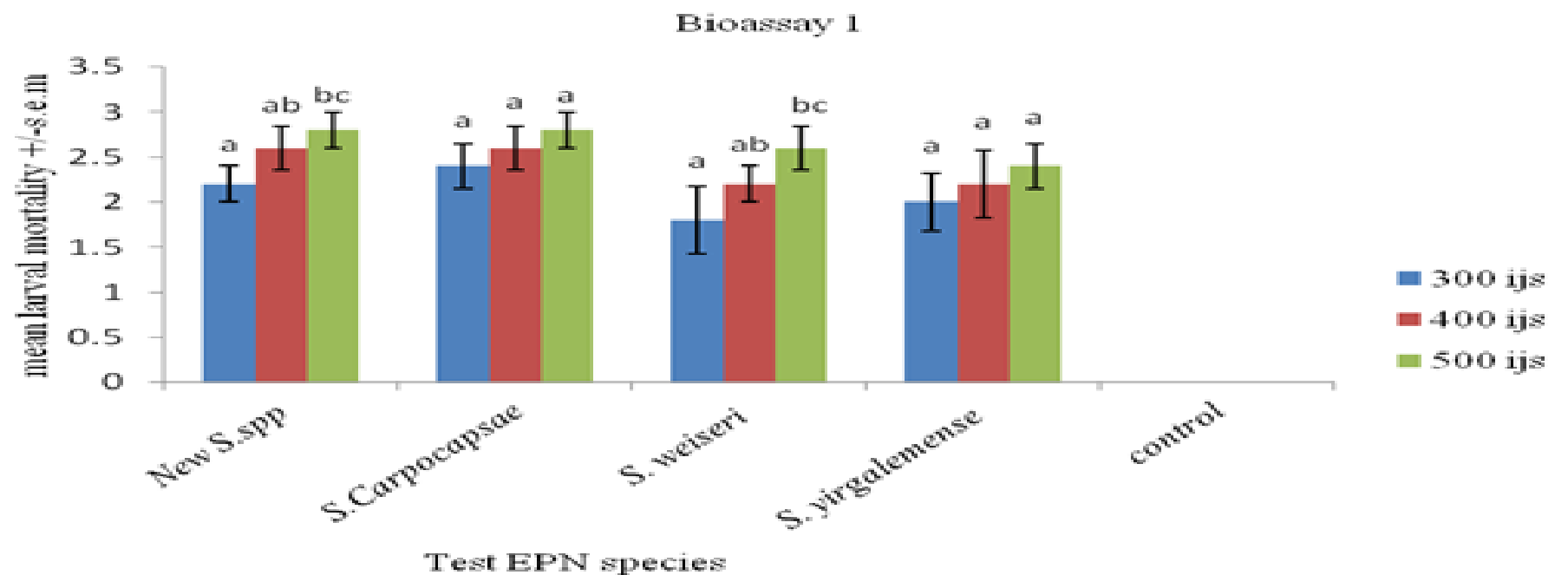

(Means with the same letter are not significantly different $(\mathrm{P} \leq 0.05$, Turkey's multiple range test). S.E.M -standard error of mean)

Figure-5. Mean mortality of banana weevil larvae following inoculation with different concentrations of infective juveniles of the selected EPNs in a dose-response assay.

Source: KALRO- Kabete

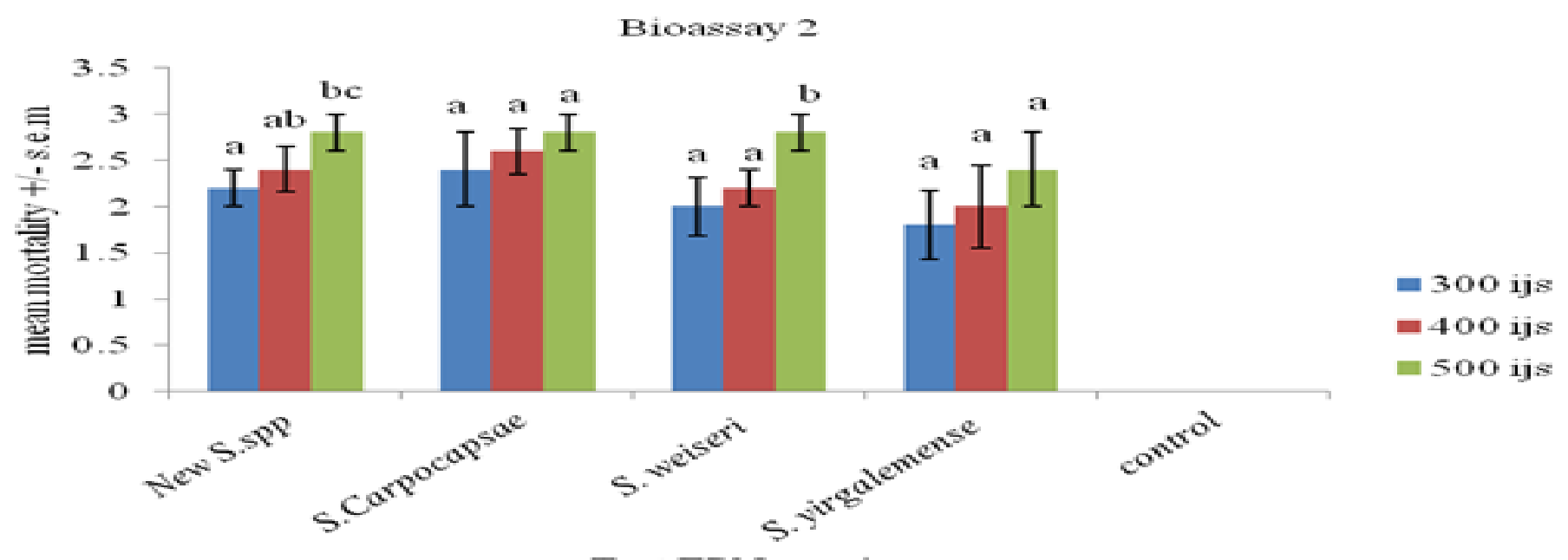

(Means with the same letter are not significantly different $(\mathrm{P} \leq 0.05$, Turkey's multiple range test). S.E.M -standard error of mean)

Figure-6. Mean mortality of banana weevil larvae following inoculation with different concentrations of infective juveniles of the selected EPNs in a dose-response assay.

Source: KALRO- Kabete 
There was a significant difference $(\mathrm{P} \leq 0.05)$ in larvae mortality between nematode concentrations 300ijs and $500 \mathrm{ijs}$ for the two nematodes new Steinernema spp and S. weiseri. However, no significant $(\mathrm{P} \geq 0.05)$ differences were observed between nematode concentrations $300 \mathrm{ijs}$ and $400 \mathrm{ijs}$ in all the test nematodes. No mortality was observed in control treatment. Test nematodes S.yirgalemense spp and new Steinernema spp did not show significant difference in all the three nematode concentrations in both bioassays. However, the trend in all the test nematodes was evident that after $96 \mathrm{hr}$ of exposure the $500 \mathrm{ijs}$ concentration caused the highest larval mortality (Figures 5 and $6)$.

\section{Discussion}

In this study, it was evident that all EPNs tested were pathogenic to Cosmopolites sordidus larvae and they caused different mortality rates under laboratory conditions. However, none of the test nematodes affected the adult stage of the banana weevil.

Although high concentrations of the test EPNs were used, the adult stage was not susceptible. This can probably be attributed to the heavily sclerotized body and pronounced long snout of the adult weevil [23] making it difficult for the Ijs to penetrate inside the weevil. Infective juveniles penetrate the host through the natural openings i.e. spiracles, mouth and anus or in some cases directly through the cuticle of certain insects [29]; [30]. According to Trevellow and Bedding [31] resistance is almost certainly due to difficulty of nematode entering the adult weevil than from establishment once infection is successful. Once inside the insect host, they work symbiotically with bacteria carried in their guts. The latter multiply releasing a number of virulence factors. These are toxin complexes, hydrolytic enzymes, hemolysins and anti-microbial compounds that cause mortality of insects within 24- 48 hours [29]; [31]. A study done by Sirjusignh, et al. [32] demonstrated similar results that local Caribbean EPNs were not effective on the adult weevil under laboratory conditions.

Furthermore, the introduction of fresh pseudo-stem laced with nematode at different dose rates was to maximize the contact between the adult weevil and the nematodes in the process of feeding. Adults are attracted to the volatiles emanating from the fresh or decomposing pseudo-stems [33]. However, no mortality was recorded. In Tanzania, a study carried out by Mwaitulo, et al. [15] reported similar results of resistance of the adult weevil to locally isolated EPNs from banana fields in three regions of Morogoro, Mbeya and Pwani.

All test EPNs caused larval mortality. These results are consistent with a study conducted in Tanzania by Mwaitulo, et al. [15] showed that all local EPN isolates were pathogenic to banana weevil larvae hence causing mortality. The test nematodes caused different mortality rates of the weevil larvae. The dead larvae got a soft consistency and a yellow to brown to black colour, characteristic of larvae killed by bacteria of the genus Xenorhabdus [28]. S. carpocapsae caused higher mean mortality compared to the rest of the test nematodes. This can be attributed to the specificity in pathogenicity and virulence of individual EPN isolate. In a study by Koppernhoofer and Fuzy [34] noted that differences in the pathogenicity of infective juveniles can be attributed to their foraging strategy, the responsiveness of the host immune system, the pathogenicity of the symbiotic bacteria and the number of bacterial cells transported by dauers. This explains why in this particular study, the test nematodes caused different mortality rates.

A report by Koppernhoofer and Kaya [35] indicated that Steinernema dauers can carry different amounts of bacterial cells in their intestines. For instance, the species $S$. scapterisci contains a small amount of bacterial cells compared to S.carpocapsae that has a large number of bacterial cells, causing higher pathogenicity but at the expense of lower survival in the environment [36]. All tested nematodes caused more than $90 \%$ mortality of the larvae. In a study conducted in Canary Island, a $100 \%$ mortality banana weevil larva was reported using indigenous EPN (Heterorhabditis and Steinernema species). Previous authors have reported susceptibility to EPNs among larvae of other beetles such as Diaprepes abbreviatus (Coleoptera: curculionidae) [37] Capnodis tenebrionis [38] and Premnotrypes sutulicallus [39]. The mortality of banana weevil larvae in this study could be attributed to the physical appearance (soft and fleshy cuticle, abdominal segments) that enabled EPNs to penetrate easily alongside the mouth and anus. Previous histopathological studies have shown that Ijs enters the larvae through the cuticle and less often through the anus and mouth [40].

From the results in this study all the test nematodes caused a significant high mean mortality rate of larvae within the first 24-48 hours of exposure. This demonstrates the high virulence and infectivity potential of the local EPNs tested against the banana weevil larval. The mortality was confirmed to be due to EPN infection through dissection of the cadavers to check for the presence of Ijs in the haemocoel. Entomopathogenic nematodes kill the host by inducing septicaemia within 24-48 hours of infection [41].

A dose-response assay showed no significant difference in larval mortality between 300ijs and 400ijs concentrations. 500 ijs concentration for all the test nematodes caused larval mortality and was different to 300ijs. This can probably be attributed to the numbers. It is said there is strength in numbers and hence the higher concentration of ijs showed high virulence and pathogenicity differences in the EPN species, humoral and immune response of the host [41].

Although there was no consistency across all the three Ijs concentrations, there was a positive relationship that weevil larval mortality increased with increasing concentrations. Larval mortality observed for S.carpocapsae and $S$. yirgalemense did not differ in the mortality rates caused to the larvae based on concentration.

The rest of the tested nematodes did not differ in causing mortality at the two concentration levels of 300ijs and 500ijs. This indicates the importance of dosage rates. The results partially concur with a study conducted by Mwaitulo, et al. [15] who reported that the banana weevil mortality increased significantly with increasing native nematode dosage. However, these same results differ with a study conducted by Padilla-Cubas, et al. [42] that showed an increase in Ijs dosage does not necessarily cause an increase of banana larvae mortality. A dose- mortality response was observed by Schmitt [43]. Previous studies have reported significant differences based on EPN 
concentration and larvae stage mortality in other insect pest orders. A study conducted in Turkey showed that native EPN Ijs concentration $(0,100,500$ and 1000ijs) had differences in causing mortality of P. operculella larvae [44].

\section{Conclusions and Recommendations}

The tested Kenyan EPNs were able to parasitize Cosmopolites sordidus larvae but not the adult under laboratory conditions. All the nematodes tested caused above $90 \%$ banana weevil larval mortality. Nematode species and the nematode concentration levels showed differences in efficiency against the weevil larvae. In addition all tested nematodes caused high mortality within 24-48 hrs of exposure indicating a high susceptibility of banana weevil larvae to the tested nematodes. These tested nematodes have potential for field management of the banana weevil since EPNs are known to search and locate susceptible hosts in cryptic habitats like within the banana pseudo-stem and corms. Larvae are found within the small holes on the surface of the rhizome, which are in contact with exterior. They are also found living in long galleries inside the rhizomes which are ideal conditions for EPNs survival and infection of hosts. The larval stage is the most destructive stage of banana weevil and if targeted for control through EPN application would lead to a reduction of banana weevil damage hence higher banana yields. The most effective EPN was S.carpocapsae and can be used at $500 \mathrm{ijs}$ concentration level in the laboratory to kill the weevil larvae

Future work is necessary to test more native nematodes for efficacy, appropriate formulations and application techniques in banana fields to enable the adoption EPNs against the banana weevil larvae in the field. In addition, further research in EPN storage is needed for longer nematode life span. Better storage and application technology of EPNs will enhance the adoption of EPNs for the management of banana weevil larvae and in the integration of entomopathogenic nematodes in pest management programs.

\section{References}

[1] R. Georgis, A. M. Koppernhoofer, and L. A. Lacey, "Successes and failures in the use of parasitic nematodes for pest control," Journal on Biological Control, vol. 38, pp. 103-123, 2006.

[2] K. Hannah, A. Ruth, A. Nelson, and W. Charles, "Effects of transgenic cotton expressing cry1Ac and cry2Ab2 protein on infectivity of the entomopathogenic nematodes, steinernema karii and heterorhabditis bacteriophora," African Journal of Agricultural Research, vol. 8, pp. 4280-4284, 2013.

[3] K. Divya and M. Sankar, "Entomopathogenic nematodes in pest management," Indian Journal of Science and Technology, vol. 2, pp. 53-58, 2009.

[4] H. R. Campos, B. Mary, W. H. Casey, and S. Patricia, "Entomopathogenic nematodes as a model system for advancing frontiers of ecology," Journal of Nematology, vol. 44, pp. 162-176, 2012.

[5] A. B. Dillon, C. P. Moore, M. J. Downes, and C. T. Griffin, "Evict or infect? Managing populations of the large pine weevil, Hylobius abietis, using a bottom-up and top-down approach," Journal of Forest Ecology and Management, vol. 255, pp. 2634-2642, 2008.

[6] R. K. Rajasekhara, S. K. Naskar, M. S. Palaniswami, and R. C. Ray, "Management of sweet potato Weevil Cylas formicarius," Journal of Pest Management, vol. 36, pp. 14-26, 2010.

[7] A. M. Martinez De, O. Strauch, C. G. Fernandez De, and P. A. Martinez, "Control of the flat-headed root borer capnodis tenebrionis (Linne) (Coleoptera: Buprestidae) with the entomopathogenic nematode steinernema carpocapsae (Weiser) (Nematoda: Steinernematidae) in a chitosan formulation in apricot orchards," Biocontrol, vol. 53, pp. 531-539, 2008.

[8] H. K. Kaya, M. M. Aguillera, A. Alfred, Y. C. Ho, and D. L. T. Marya, "Status of entomopathogenic nematodes and their symbiotic bacteria from selected countries or regions of the world," Journal on Biological Control, vol. 38, pp. 134-155, 2006.

[9] S. Hazir, H. K. Kaya, S. P. Stock, and N. Keskin, "Entomopathogenic nematodes (Steinernematidae and Heterorhabditidae) for biological control of soil pests," Turkish Journal of Biology, vol. 27, pp. 181-202, 2004.

[10] F. Akyazi, M. A. Ansari, B. I. Ahmed, W. T. Crow, and T. Mekete, "First record of entomopathogenic nematodes (Steinernematidae and Heterorhabditidae) from Nigerian soil and their morphometrical and ribosomal DNA sequence analysis," Journal on Nematology, vol. 40, pp. 95-100, 2012.

[11] M. M. Shamseldean, E.-S. A. Abou, M. M. Abd-Elgawad, and M. M. Saleh, "Identification of a new heterorhabditis species from Egypt. heterorhabditis taysearae n. sp. Rhabditida: Heterorhabditidae," Egyptian Journal of Biological Pest Control, vol. 6, pp. 129138, 1996.

[12] A. M. Burnell and S. P. Stock, "Heterorhabditis, steinernema and their bacterial symbionts: Lethal pathogens of insects," Journal on Nematology, vol. 2, pp. 31-42, 2000.

[13] K. B. Nguyen, D. I. Shapiro-Ilan, R. J. Stuart, C. W. McCoy, R. R. James, and B. J. Adams, "Heterorhabditis Mexicana n. sp. (Rhabditida: Heterorhabditidae) from Tamaulipa, Mexico, and morphological studies of the bursa of heterorhabditis spp," Nematology, vol. 6, pp. 231-244, 2004.

[14] T. Mekete, R. Gaugler, K. B. Nguyen, W. Mandefro, and M. Tessera, "Biogeography of entomopathogenic nematodes in Ethiopia," Journal on Nematropica, vol. 35, pp. 31-36, 2005.

[15] S. Mwaitulo, S. Haukeland, M. G. Sæthre, A. Laudisoit, and A. P. Maerere, "First report of entomopathogenic nematodes from Tanzania and their virulence against larvae and adults of the banana weevil cosmopolites sordidus coleoptera: Curculionidae," International Journal of Tropical Insect Science, vol. 31, pp. 154-161, 2011.

[16] A. P. Malan, R. Knoetze, and S. D. Moore, "Isolation and identification of entomopathogenic nematodes from citrus orchards in South Africa and their biocontrol potential against false codling moth," Journal of Invertebrate Pathology, vol. 8, pp. 115-125, 2011. F. N. Kanga, L. Waeyenberge, S. Hauser, and M. Moens, "Distribution of entomopathogenic nematodes in Southern Cameroon," Journal of Invertebrate and Pathology, vol. 106, pp. 41-51, 2012.

[18] C. N. Waturu, D. J. Hunt, and A. P. Reid, "Steinernema karii sp N (Nematoda): Steinernematidae, a new entomopathogenic nematode from Kenya," International Journal of Nematology, vol. 7, pp. 68-75, 1997.

[19] C. N. Waturu, "Entomopathogenic nematodes (Steinernematidae and Heterorhabitidae) from Kenya," PhD Thesis, University of Reading, U.K, 1998.

[20] R. Gaugler, Entomopathogenic nematology. Wallingford, UK: CABI Publishing, 2002.

[21] S. W. Mwaniki, J. H. Nderitu, F. Olubayo, J. W. Kimenju, and K. Nguyen, "Factors influencing the occurrence of entomopathogenic nematodes in the central rift valley region of Kenya," African Journal of Ecology, vol. 46 pp. 79-84, 2008.

[22] C. S. Gold and S. Messiaen, "The banana weevil, cosmopolites sordidus. Musa pest fact sheet No. 4," Parc Scientifique Agropolis II, 34397 Montpellier, France, 2000.

[23] N. Treverrow, Banana weevil borer. Agfact H6.AE.1. 3rd Edn., Agdex 231/622. Centre for Tropical Horticulture Alstonville, NSW Agriculture, 2003.

[24] W. Tinzaara, C. S. Gold, M. Dicke, H. A. Van, and P. E. Ragama, "Effect of mulching on banana weevil movement relative to pheromone traps," African Crop Science Journal, vol. 16, pp. 59-66, 2008.

[25] J. G. O. Poinar, Nematodes for biological control of insects. Boca Raton: CRC Press, 1979. 
[26] J. L. Woodring and H. K. Kaya, Sternematidae and Heterorhabditidae nematodes. A Handbook of Biology and Techniques. Nemathode Subcommittee on the Southern Regional Project S135 - Entomopathogens for use in Pest Management Systems, Arkansas: Southern Cooperative, Series Bulletin, No.331, 1988.

[27] J. R. Parra, "Insect breeding for studies with pathogens. In: Alves, S. B. (D). Microbial control of insects, Agrarian studies Luiz de Quiroz foundation," Piracicaba, vol. 35, pp. 1015-1037, 1998.

[28] A. Koppernhoofer, Field manual of techniques in invertebrates pathology, application and evaluation of pathogens for control of insects and other invertebrate pests, 2nd ed. Netherlands: Kluwer Academic Publishers Dordrecht, 2007.

[29] R. H. French, A. Dowling, and N. R. Waterfield, "Insecticidal toxins from photorhabdus bacteria and their potential use in agriculture," Toxicon, vol. 49, pp. 436-451, 2007.

[30] I. Eleftherianos, S. Joyce, R. H. Ffrench-Constant, D. J. Clarke, and S. E. Reynolds, "Probing the tri-trophic interaction between insects, nematodes and photorhabdus," Parasitology, vol. 137, pp. 1695-1706, 2010.

[31] N. L. Trevellow and R. A. Bedding, "Development of a system for the control of the banana weevil borer with entomopathogenic nematodes," Biological Control of Insects Pests, pp. 41-47, 1993.

[32] C. Sirjusignh, H. Mauleon, and A. Kermarrec, "Compatibility and synergism between entomopathogenic nematodes and pesticides for control of cosmopolite's sordidus," in Proceedings of Caribbean meetings in Biological Control 5-7 November. Guadeloupe, F.W.I, 1991, pp. 183-192.

[33] M. Masanza, C. S. Gold, A. Huisb, P. E. Ragama, and S. H. Oketch, "Effect of crop sanitation on banana weevil cosmopolites sordidus (Germar) (Coleoptera: Curculionidae) populations and crop damage in farmers' fields in Uganda," Journal on Crop Protection, vol. 24, pp. 275-283, 2005.

[34] A. Koppernhoofer and E. Fuzy, "Sterneinerma scarabei for the control of white grubs," Biological Control, vol. 28, pp. 47-59, 2003.

[35] A. Koppernhoofer and H. K. Kaya, "Ecological characterization of steinernema rarum," Journal of Invertebrates Pathology, vol. 73, pp. 120-128, 1999.

[36] V. M. Emelianoff, N. Sicard, C. Le Braun, and J. B. Ferdy, "Effect of bacterial symbionts Xenorhabdus on mortality of infective juveniles of two steinernema species," Parasitology Research, vol. 100, pp. 657-659, 2007.

[37] D. A. Jenkins, D. Shapiro-Ilan, and R. Geonaga, "Efficacy of entomopathogenic nematodes versus diaprepes abbreviatus (Coleoptera: Curculionidae) larvae in a high clay-content oxisol soil; Greenhouse trials with potted Litchi Chinensis," Florida Entomologists, vol. 91, pp. 75-78, 2008.

[38] D. P. Garcia and A. Morton, "Efficacy of entomopathogenic nematodes against neonate of capnodis tenebrionis (L) (Coleoptera: Buprestidae) in laboratory trials," Biocontrol, vol. 50, pp. 307-316, 2005.

[39] S. Parsa, J. Alcazar, and H. K. Kaya, "Indigenous Peruvian entomopathogenic nematodes for suppression of the Andean potato weevil," Biological, vol. 39, pp. 171-178, 2006.

[40] C. M. Dolinski, E. Del Valle, and R. J. Stuart, "Virulence of entomopathogenic nematodes to larvae of the guava weevil conotrachelus psidii (Coleoptera: Curculionidae) in laboratory and greenhouse experiment," Biological Control, vol. 38, pp. 422-427, 2006.

[41] C. T. Griffin, N. E. Boemare, and E. E. Lewis, Biology and behavior In: Grewal, P.S., Ehlers, R.U and Shapiro-Ilan, D.I (Eds). Nematode as biocontrol agents. Wallingford, U.K: CABI Publishing, 2005.

[42] A. Padilla-Cubas, A. C. Hernandez, and D. P. F. Garcia, "Laboratory efficacy against neonate larvae of the banana weevil of two indigenous entomopathogenic nematodes species from Canary Islands Spain," International Journal of Pest Management, vol. 56, pp. 211-216, 2010.

[43] A. T. Schmitt, "Biological control of the banana weevil (Cosmopolite's Sordidus) with entomopathogenic nematodes," PhD Thesis, University of Reading, Reading, U.K, 1993.

[44] I. Kepenecki, A. Tulek, M. Alkan, and S. Hazir, "Biological control potential of native entomopathogenic nematodes against potato tuber moth (Pthorimea operculella (Zeller) (Lepidoptera: Gelechiidae) in Turkey," Pakistan Journal of Zoology, vol. 45, pp. 1415$1422,2013$. 